Retraction

\title{
Retracted: Calibration of the Live Load Factor for Highway Bridges with Different Requirements of Loading
}

\author{
Advances in Civil Engineering \\ Received 3 June 2020; Accepted 3 June 2020; Published 17 August 2020 \\ Copyright (C) 2020 Advances in Civil Engineering. This is an open access article distributed under the Creative Commons \\ Attribution License, which permits unrestricted use, distribution, and reproduction in any medium, provided the original work is \\ properly cited.
}

Advances in Civil Engineering has retracted the article titled "Calibration of the Live Load Factor for Highway Bridges with Different Requirements of Loading” [1].

The data are from the California Department of Transportation (Caltrans) research project "P285 LRFD and LRFR Specifications for Permits and Fatigue Truck Loads" managed by Dr. Gongkang Fu, who did not provide permission to use these data or to use unpublished reports by Dr. Fu.

The Chief Editor has approved retraction, and the authors apologise.

\section{References}

[1] L. Liu, Q. Ren, and X. Wang, "Calibration of the Live Load Factor for Highway Bridges with Different Requirements of Loading," Advances in Civil Engineering, vol. 2020, Article ID 7347593, 10 pages, 2020. 